ISSN: 1979-7362

\title{
Perubahan Lahan Tambak di Kecamatan Biringkanaya Kota Makassar Menggunakan Citra Satelit Resolusi MenengahTahun 2010 dan 2016
}

\author{
Abd. Malik ${ }^{1}$, Totok Prawitosari ${ }^{1}$ dan Sitti Nur Faridah ${ }^{1}$ \\ 1)Program Studi Teknik Pertanian, Universitas Hasanuddin Makassar
}

\begin{abstract}
ABSTRAK
Lahan tambak merupakan salah satu jenis dari lahan pertanian. Secara umum, Tambak merupakan kolam yang dibangun di daerah pasang surut dan digunakan untuk memelihara bandeng, udang laut dan hewan air lainnya yang biasa hidup di air payau. Dalam kegiatan alih fungsi lahan sangat erat kaitannya dengan permintaan dan penawaran lahan, dimana penawaran atau persediaan lahan sangat terbatas sedangkan permintaan lahan yang tidak terbatas. Perubahan lahan dapat di lihat dengan pendekatan menggunakan Sistem Informasi Geografis (SIG) untuk menambah informasi yang akan didapat, seperti sistem input data peta yang baik. Pendekatan ini menerapkan teknologi berbasis geospasial. Tujuan dari penelitian ini adalah untuk memetakan dan mengidentifikasi penyebaran lahan tambak dengan menggunakan citra satelit resolusi menengah di kecamatan Biringkanaya kota Makassar pada tahun 2010 dan 2016. Adapun prosedur dalam penelitian ini dilaksanakan dengan tahapan pengumpulan data batas administrasi Kecamatan. Citra Satelit Landsat 8 tahun 2016 dan Citra Satelit SPOT 4 tahun 2010. Kemudian Komposit Citra, Koreksi Radiometrik, Koreksi Geometrik, Pengambilan Lokasi Sampel (Training Area) dan Analisis Keakuratan. Berdasarkan hasil penelitian maka diperoleh Perubahan lahan di Kecamatan Biringkanaya Kota Makassar pada tahun 2010 hingga 2016 yaitu lahan tambak yang tetap sebagai lahan tambak sebesar 161,8 ha (5\%), lahan tambak menjadi lahan pemukiman sebesar 160,37 ha (4\%), lahan pemukiman menjadi lahan tambak sebesar 31,4 ha (1\%) dan lahan pemukimantetap sebagai lahan pemukiman sebesar 3321,83 ha (90\%).
\end{abstract}

Kata kunci: lahan, SIG, Citra Satelit, dan Peta

\section{PENDAHULUAN}

\section{Latar Belakang}

Lahan tambak merupakan salah satu jenis dari lahan pertanian. Secara umum, Tambak merupakan kolam yang dibangun di daerah pasang surut dan digunakan untuk memelihara bandeng, udang laut dan hewan air lainnya yang biasa hidup di air payau. Air yang masuk ke dalam tambak sebagian besar berasal dari laut saat terjadi pasang. Kebutuhan air tawar dipenuhi dari sungai yang bermuara di laut.

Dalam kegiatan alih fungsi lahan sangat erat kaitannya dengan permintaan dan penawaran lahan, dimana penawaran atau persediaan lahan sangat terbatas sedangkan permintaan lahan yang tidak terbatas. Menurut Barlowe (1978), faktor- faktor yang mempengaruhi penawaran lahan adalah karakteristik fisik alamiah, faktor ekonomi, faktor teknologi, dan faktor kelembagaan. Selain itu, faktorfaktor yang mempengaruhi permintaan lahan adalah populasi penduduk, perkembangan teknologi, kebiasaan dan tradisi, pendidikan dan kebudayaan, selera dan tujuan, serta perubahan sikap dan nilai yang disebabkan oleh perkembangan usia.

Berdasarkan BPS (2013) salah satu daerah yang memiliki lahan tambak yang telah mengalami alih fungsi lahan kepemukiman yaitu Kecamatan Biringkanaya. Kecamatan Biringkanaya merupakan kecamatan terluas diantara kecamatan-kecamatan lain yang ada di Kota Makassar, luasnya 48,22 km2 atau sekitar 27,43\% dari luas keseluruhan Kota 
Makassar dan berbatasan langsung dengan Kabupaten Maros. Topografi wilayah kecamatan ini mulai dari dataran rendah hingga dataran tinggi dengan ketinggian elevasi 1-19 $\mathrm{m}$ di atas permukaan laut. Potensi sumberdaya alam yang ada di kecamatan ini antara lain di sektor pertanian dan perikanan. Subsektor pertanian, luas lahan peruntukannya sebagai lahan sawah yakni 657 ha dan lahan tegalan 284 ha. Subsektor perikanan darat, luas lahan peruntukan sebagai tambak 479 ha dengan produksi 149,80 ton.

Perubahan lahan dapat di lihat dengan pendekatan menggunakan Sistem Informasi Geografis (SIG) untuk menambah informasi yang akan didapat, seperti sistem input data peta yang baik. Pendekatan ini menerapkan teknologi berbasis geospasial. SIG memiliki kemampuan untuk mempresentasikan unsur-unsur yang terdapat di permukaan bumi dengan cara mengumpulkan, menyimpan, memanipulasi, menganalisa dan menampilkan kembali kondisi-kondisi alam (bereferensi geografis).

Berdasarkan uraian di atas dan potensi yang ada di kecamatan Biringkanaya, maka perlu dilakukan penelitian dengan Sistem Informasi Geografis (SIG) mengenai perubahan lahan tambak di kecamatan Biringkanaya kota Makassar menggunakan citra satelit resolusi menengah tahun 2010 dan 2016 untuk membuktikan kenyataan yang ada dilapangan dengan hasil klasifikasi dari citra satelit.

\section{Rumusan Masalah}

Adapun rumusan masalah pada penelitian ini yaitu:

1. Berapa persentase lahan tambak yang terkonversi menjadi pemukiman dari Tahun 2010-2016?

2. Berapa persentase tingkat keakuratan klasifikasi citra satelit resolusi menengah untuk perubahan lahan
Tambak di Kecamatan Biringkanaya kota Makassar?

\section{Tujuan dan Kegunaan}

Tujuan dari penelitian ini adalah untuk memetakan dan mengidentifikasi penyebaran lahan tambak dengan menggunakan citra satelit resolusi menengah di kecamatan Biringkanaya kota Makassar pada tahun 2010 dan 2016.

Kegunaan dari penelitian ini adalah sebagai dasar informasi tentang perubahan penggunaan lahan tambak yang telah terjadi di Kecamatan Biringkanaya Kota Makassar pada tahun 2010 dan 2016.

\section{METODOLOGI}

\section{Waktu dan Tempat}

Penelitian ini akan dilaksanakan pada bulan Juni 2017 - Agustus 2017 di wilayah Kecamatan Biringkanaya, Kota Makassar, Provinsi Sulawesi Selatan.

\begin{abstract}
Alat dan Bahan
Alat yang digunakan dalam penelitian ini adalah satu unit komputer, software pengolah data citra, Global Positioning System (GPS), dan software pengolah data SIG.

Bahan yang digunakan adalah Citra Satelit Landsat 8 Tahun 2016, Citra Satelit SPOT 4 Tahun 2010, serta data vektor berupa file shpKecamatan Biringkanaya, Kota Makassar.
\end{abstract}

\section{Prosedur Penelitian}

Adapun prosedur dalam penelitian ini dilaksanakan dengan tahapan sebagai berikut:

1. Pengumpulan Data

Pengumpulan data adalah tahap pengumpulan data-data yang meliputi pengadaan data yang akan digunakan dalam penelitian. Adapun data yang digunakan adalah sebagai berikut:

a. Data batas administrasi Kecamatan Biringkanaya, Kota Makassar (BPS, 2010) 
b. Citra Satelit Landsat 8 tahun 2016 dan Citra Satelit SPOT 4 tahun 2010.

c. Peta Rupa Bumi Kota Makassar (Badan Informasi Geospasial, 2016).

d. Data luas lahan Kota Makassar (Kecamatan Biringkanaya dalam Angka, 2014).

2. Komposit Citra

Komposit citra yaitu menggabungkan 3 band yaitu Red, Green, dan Blue yang bertujuan untuk memudahkan identifikasi warna dari penggunaan lahan. Untuk mengidentifikasi penggunaan lahan, digunakan band 6, 5 dan 4 pada Citra Satelit Landsat dan digunakan 4, 1 dan 3 pada Citra Satelit SPOT 4.

3. Memotong (Cropping)

Data Citra Cropping bertujuan untuk memotong citra sesuai dengan batas daerah penelitian. Cropping citra ini menggunakan software ArcView GIS dengan tetap memperhatikan cakupan citra yang dianalisis. Cakupan citra yang digunakan diambil dari wilayah yang tercakup dalam ke-3 scene data yang akan diolah.

4. Koreksi Radiometrik

Koreksi radiometrik merupakan pembetulan citra akibat kesalahan radiometrik atau cacat radiometrik. Koreksi radiometrik ini bertujuan untuk memperbaiki nilai piksel agar sesuai dengan warna asli.

5. Koreksi Geometrik

Koreksi geometrik merupakan pembetulan mengenai posisi citra akibat kesalahan geometrik. Koreksi geometrik dilakukan dengan menggunakan acuan titik kontrol yang dikenal dengan Ground Control Point (GCP).

6. Pengambilan Lokasi Sampel (Training Area)

Pengambilan lokasi sampel dilakukan pada lokasi yang teridentifikasi sebagai tambak dan pemukiman, dilanjutkan membuat analisis Training Area dengan cara melakukan digitasi titik koordinat kedalam citra berdasarkan titik koordinat lokasi sampel masing-masing.

7. Mengklasifikasi Training Area

Klasifikasi training area dilakukan berdasarkan pengelompokkan training area yang telah dilakukan sebelumnya, sehingga terbaca berdasarkan warna yang telah ditetapkan.

8. Validasi Data

Validasi data adalah cara yang digunakan untuk mengetahui akurasi citra dalam mengelompokkan objek yang teridentifikasi sebagai jenis-jenis penutupan lahan yang sesuai fungsinya. Prosedur melakukan validasi data adalah sebagai berikut:

a. Mencatat koordinat-koordinat lokasi yang diidentifikasi oleh citra sebagai kelas-kelas penggunaan yang dibutuhkan untuk hasil citra.

b. Mengecek lokasi yang diidentifikasi oleh citra sebagai kelas-kelas penggunaan yaitu tambak dan pemukiman.

c. Mencatat jumlah lokasi yang diidentifikasi sebagai tambak dan pemukiman serta terbukti sebagai tambak atau pemukiman.

d. Mencatat jumlah lokasi yang diidentifikasi sebagai tambak dan pemukiman tetapi bukan tambak dan pemukiman.

e. Mengulang poin (a) sampai (d) di atas untuk lokasi penggunaan lain.

9. Analisis Keakuratan

Analisis keakuratan digunakan untuk menghitung tingkat akurasi klasifikasi terpantau. Persamaan yang digunakan adalah:

a. Prosedur menghitung User Accuracy

$$
U=\frac{z}{\text { NFakta }} \times 100 \%
$$

Keterangan:

$\mathrm{Z}=$ Jumlah koordinat yang terbukti pada validasi

$\mathrm{N}$ Fakta $=$ jumlah koordinat validasi 
b. Prosedur menghitung Produser Accuracy

$P=\frac{z}{\text { NFakta }} \times 100 \%$

Keterangan :

$\mathrm{Z}=$ Jumlah koordinat yang terbukti pada validasi

$\mathrm{N}$ Fakta $=$ Jumlah koordinat setelah validasi

c. Prosedur menghitung Overal Accuracy

Overal Accuracy $=\frac{X}{N} \times 100 \%$

Keterangan:

$\mathrm{X}=$ Jumlah total yang terbukti pada validasi

$\mathrm{N}=$ Jumlah total yang divalidasi

d. Menghitung Koefisien Persen Matriks

$K_{\text {hat }}=\frac{N \sum_{i=1}^{r} x i i-\sum_{i=1}^{r}\left(X_{i+} * X_{+i}\right)}{N^{2}-\sum_{i=1}^{r}\left(X_{i+} * X_{+i}\right)}$

Keterangan:

$K_{\text {hat }}=$ Koefisien Kappa

$\mathrm{N}=$ Jumlah sampel matriks

$\sum_{i=1}^{r} x i i=$ Perkalian dari penjumlahan

diagonal matriks

$\sum_{i=1}^{r}\left(X_{i+} * X_{+i}\right)=$ Perkalian dari

penjumlahan antar baris kolom

Tabel 1. Tingkat Akurasi Citra

\begin{tabular}{|c|c|c|c|c|}
\hline $\begin{array}{c}\text { Jenis } \\
\text { Lahan }\end{array}$ & $\begin{array}{c}\text { Produs } \\
\text { er } \\
\text { Accura } \\
\text { cy (\%) }\end{array}$ & $\begin{array}{c}\text { Omnisio } \\
\text { n Error } \\
\text { (\%) }\end{array}$ & $\begin{array}{c}\text { User } \\
\text { Accurac } \\
y(\%)\end{array}$ & $\begin{array}{c}\text { Commisi } \\
\text { on Error } \\
(\%)\end{array}$ \\
\hline Tambak & & & & \\
\hline $\begin{array}{c}\text { Pemukim } \\
\text { an }\end{array}$ & & & & \\
\hline
\end{tabular}

10. Output

Adapun output dari hasil penelitian ini adalah layout peta dasar klasifikasi lahan tambak dan pemukiman yang terdapat di Kecamatan Biringkanaya, Kota Makassar tahun 2010 dan 2016.
Diagram Alir Penelitian

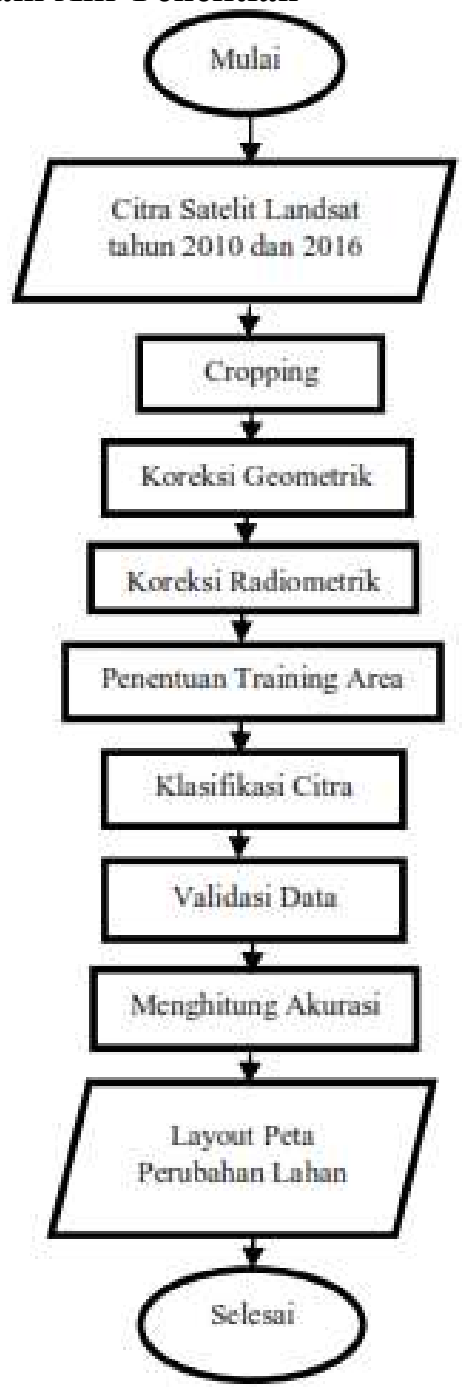

Gambar 1. Diagram Alir Penelitian

\section{HASIL DAN PEMBAHASAN}

\section{Keadaan Umum Lokasi Penelitian}

Kota Makassar secara geografi terletak pada koordinat $119^{\circ} 24^{\prime} 17,38^{\prime \prime}$ BT dan5 ${ }^{\circ}$ '6,19" LS dengan ketinggian yang bervariasi antara 1-25 meter dari permukaan laut. Kondisi topografi daerah relatif mendatar dengan kemiringan $0-5^{\circ}$ ke arah Barat, diapitdua muara sungai yakni Sungai Tallo yang bermuara di bagian Utara kota dan SungaiJeneberang yang bermuara di Selatan kota. Total luas daerah Kota Makassar kuranglebih 17.577 ha termasuk 11 pulau di Selat Makassar 
dan luas wilayah perairan kurang lebih 100 $\mathrm{km}^{2}$ (BPS, 2013).

Kecamatan Biringkanaya terdiri dari 7 kelurahan dengan luas wilayah 4822 ha. Secara administrasi luas setiap kelurahan yaitu kelurahan Paccerakkang seluas 780 ha, kelurahan Daya 581 ha, Kelurahan Pai 541 ha, kelurahan Sudiang Raya seluas 878 ha, kelurahan sudiang 1.349 ha, kelurahan Bulurokeng seluas 431 ha, dan kelurahan Untia seluas 289 ha (Biringkanaya Dalam Angka, 2014).

Kecamatan Biringkanaya merupakan salah satu dari 14 Kecamatan di Kota Makassar yang berbatasan dengan Kabupaten Maros di sebelah utara, Kabupaten Maros di sebelah timur, Kecamatan Tamalanrea di sebelah selatan, dan Kecamatan Tallo disebelah barat. Kecamatan Biringkanaya merupakan daerah bukan pantai dengan topografi ketinggian antara permukaan laut. Menurut jaraknya, letak masing-masing kelurahan ke ibukota Kecamatan berkisar $1 \mathrm{~km}$ sampai dengan jarak 5-10 km (Biringkanaya Dalam Angka, 2014).

\section{Klasifikasi Citra}

Setelah proses pengolahan citra seperti koreksi geometrik untuk memperbaiki nilai pergeseran bumi, koreksi radiometrik untuk memperbaiki nilai piksel dari citra, melakukan pemotongan, serta melakukan identifikasi lahan diperoleh hasil klasifikasi dengan menggunakan citra tahun 2010 dan 2016. Klasifikasi penutupan lahan diperoleh melalui pengolahan citra menggunakan sistem training area. Training area dilakukan dengan cara mendigitasi titik koordinat pada citra berdasarkan titik koordinat lokasi pengambilan sampel. Interpretasi pada penelitian ini di khususkan pada lahan tambak yang terdapat di Kecamatan Biringkanaya di Kota Makassar.

\section{Perubahan Penggunaan Lahan}

Berdasarkan hasil klasifikasi citra SPOT 4 tahun 2010 dan citra landsat 8 tahun 2016 diperoleh hasil :

\section{Penggunaan Lahan Tahun 2010}

Pada proses interpretasi, citra SPOT 4 tahun 2010 menghasilkan data penggunaan lahan di kecamatan Biringkanaya menjadi 2 kelas yaitu tambak dan pemukiman. Perbedaan luas penggunaan lahan tahun 2010 pada kecamatan Biringkanaya dapat dilihat dari hasil koreksi berupa persebaran warna tiap kelas tutupan dan penggunaan lahan.

Peta hasil klasifikasi penggunaan lahan pada tahun 2010 kecamatan Biringkanaya disajikan pada Gambar 2.

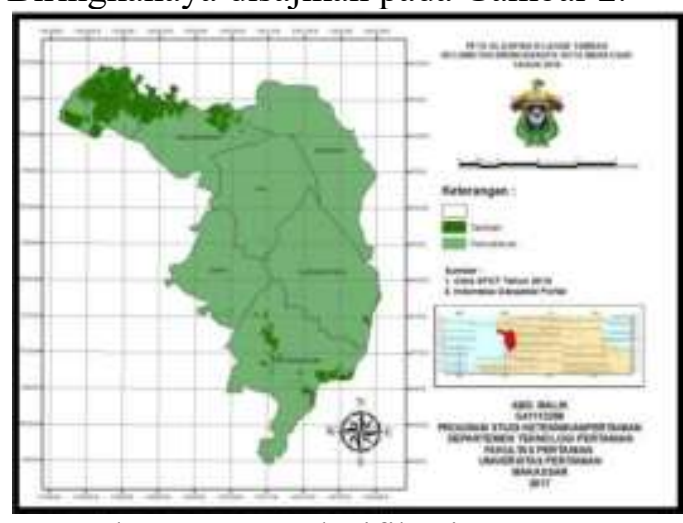

Gambar 2. Peta Klasifikasi Kecamatan Biringkanaya Tahun 2010

Berdasarkan Berdasarkan Tabel 4. dan Gambar 3. hasil klasifikasi Citra SPOT 4 tahun 2010, menunjukkan bahwa area terluas adalah pemukiman, yang memiliki luas mencapai 3.354,22 ha. Dan penggunnaan lahan kedua yaitu tambak dengan luas sebesar 329,17 ha.

Tabel 2. Hasil Klasifikasi Citra SPOT 4

\begin{tabular}{|l|c|c|c|}
\hline No. & $\begin{array}{c}\text { Penggunaan } \\
\text { Lahan }\end{array}$ & $\begin{array}{c}\text { Luas } \\
\text { Area } \\
\text { (ha) }\end{array}$ & $\begin{array}{c}\text { Persentase } \\
\text { (\%) }\end{array}$ \\
\hline 1. & Tambak & 329,17 & 9 \\
\hline 2. & Pemukiman & $3,354,22$ & 91 \\
\hline \multicolumn{2}{|c|}{ Total } & $\mathbf{3 6 8 3 , 3 9}$ & $\mathbf{1 0 0}$ \\
\hline
\end{tabular}




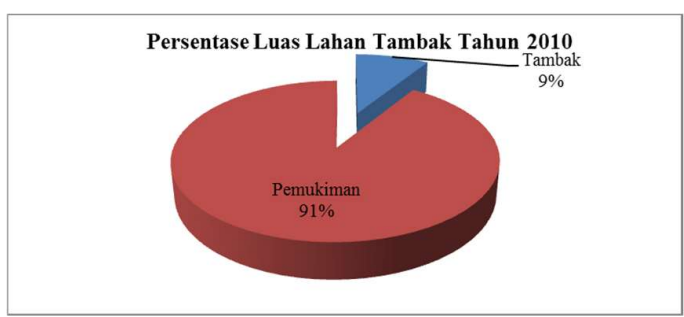

Gambar 3. Diagram Persentase Luas

Lahan Tambak dan Pemukiman Kecamatan Biringkanaya

Tahun 2010

\section{Penggunaan Lahan Tahun 2016}

Pada proses interpretasi, citra Landsat 8 tahun 2016 menghasilkan data penggunaan lahan di kecamatan Biringkanaya menjadi 2 kelas yaitu tambak dan pemukiman. Perbedaan luas penggunaan lahan tahun 2016 pada kecamatan Biringkanaya dapat dilihat dari hasil koreksi berupa persebaran warna tiap kelas tutupan dan penggunaan lahan.

Peta hasil klasifikasi penggunaan lahan pada tahun 2016 kecamatan Biringkanaya disajikan pada Gambar 4.

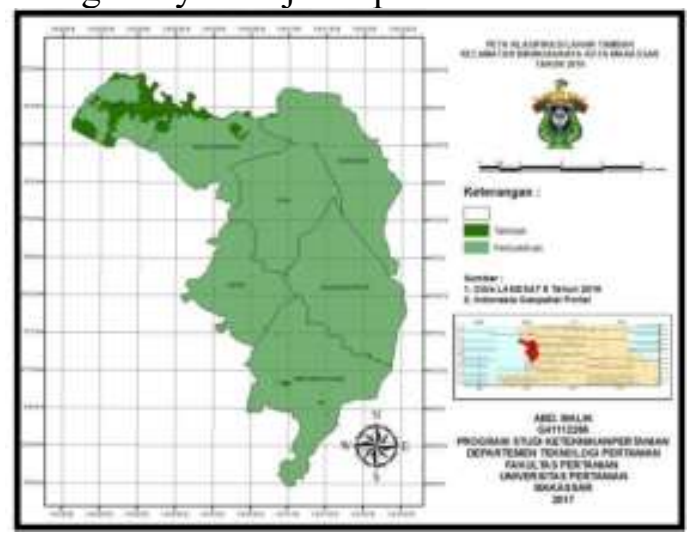

Gambar 4. Peta Klasifikasi Kecamatan Biringkanaya Tahun 2016

Berdasarkan Berdasarkan Tabel 3. dan Gambar 5. hasil klasifikasi Citra Landsat 8 tahun 2016, menunjukkan bahwa area terluas adalah pemukiman, yang memiliki luas mencapai 3.354,22 ha. Dan penggunnaan lahan kedua yaitu tambak dengan luas sebesar 329,17 ha.
Tabel 3. Hasil Klasifikasi Citra Landsat 8 Tahun 2016

\begin{tabular}{|l|c|c|c|}
\hline No. & $\begin{array}{c}\text { Penggunaan } \\
\text { Lahan }\end{array}$ & $\begin{array}{c}\text { Luas } \\
\text { Area } \\
\text { (ha) }\end{array}$ & $\begin{array}{c}\text { Persentase } \\
(\mathbf{\%})\end{array}$ \\
\hline 1. & Tambak & 200,2 & 5 \\
\hline 2. & Pemukiman & $3.483,19$ & 95 \\
\hline \multicolumn{2}{|c|}{ Total } & $\mathbf{3 6 8 3 , 3 9}$ & $\mathbf{1 0 0}$ \\
\hline
\end{tabular}

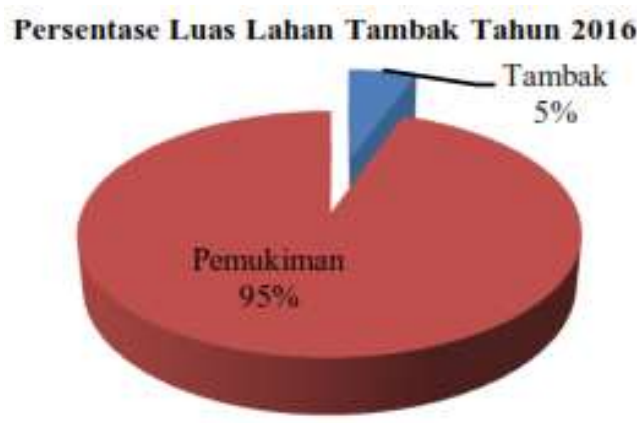

Gambar 5. Diagram Persentase Luas Lahan Tambak dan Pemukiman Kecamatan Biringkanaya Tahun 2016

\section{Perubahan Penggunaan Lahan Tahun 2010-2016}

Berdasarkan hasil klasifikasi citra SPOT 4 tahun 2010 dan citra Landsat 8 tahun 2016, menunjukkan bahwa selisih perubahan lahan tambak menjadi pemukiman dapat dilihat pada Tabel 4 . berikut ini :

Tabel 4. Perubahan Penggunaan Lahan Tahun 2010 dan 2016

\begin{tabular}{|c|c|c|c|c|c|c|c|}
\hline \multirow{2}{*}{ No. } & \multirow{2}{*}{$\begin{array}{c}\text { Penggun } \\
\text { aan } \\
\text { Lahan }\end{array}$} & \multicolumn{2}{|c|}{ Tahun 2010} & \multicolumn{2}{|c|}{ Tahun 2016} & \multicolumn{2}{|c|}{ Perubahan } \\
\hline & & $\mathrm{Ha}$ & $\%$ & $\mathrm{Ha}$ & $\%$ & $\mathrm{Ha}$ & $\%$ \\
\hline 1. & Tambak & 329,17 & 9 & 200,2 & 5 & 128,97 & 4 \\
\hline 2. & $\begin{array}{c}\text { Pemukim } \\
\text { an }\end{array}$ & $\begin{array}{c}3.354,2 \\
2\end{array}$ & 91 & $\begin{array}{c}3.483,1 \\
9\end{array}$ & 95 & $\begin{array}{c}++ \\
128,97\end{array}$ & 4 \\
\hline \multicolumn{2}{|c|}{ Total } & $\begin{array}{c}3683,3 \\
9 \\
\end{array}$ & $\begin{array}{c}10 \\
0 \\
\end{array}$ & $\begin{array}{c}3683,3 \\
9 \\
\end{array}$ & $\begin{array}{c}10 \\
0 \\
\end{array}$ & & \\
\hline
\end{tabular}




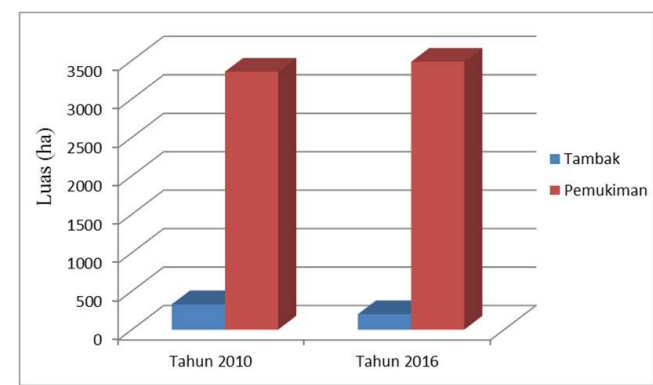

Gambar 6. Grafik Penggunaan Lahan

Tahun 2010 dan 2016 di

Kecamatan Biringkanaya

Pada Tabel 4. di atas, menunjukkan bahwa pada tahun 2010-2016, lahan tambak menurun. Dapat dilihat bahwa pada tahun 2010 luas tambak mencapai 329,17 ha dan menurun pada tahun 2016 sebesar 200,2 ha. Sedangkan pemukiman mengalami peningkatan dari 3354,22 ha menjadi 3483,19 ha.

Dari data diatas, dapat disimpulkan bahwa pada rentang waktu 6 tahun, telah terjadi alih fungsi lahan. Hal ini sesuai dengan pendapat Utomo (1989), bahwa alih fungsi lahan dalam artian perubahan/penyesuaian peruntukan penggunaan, disebabkan oleh faktor-faktor yang secara garis besar meliputi keperluan untuk memenuhi kebutuhan penduduk yang makin bertambah jumlahnya dan meningkatnya tuntutan akan mutu kehidupan yang lebih baik. Kebutuhan lahan untuk kegiatan nonpertanian cenderung terus meningkat seiring dengan peningkatan jumlah penduduk dan perkembangan struktur perekonomian. Alih fungsi lahan pertanian sulit dihindari akibat kecenderungan tersebut.Alih fungsi lahan biasanya terkait dengan proses perkembangan wilayah, bahkan dapat dikatakan bahwa alih fungsi lahan merupakan konsekuensi dari perkembangan wilayah. Sebagian besar alih fungsi lahan yang terjadi, menunjukkan adanya ketimpangan dalam penguasaan lahan yang lebih didominasi oleh pihak kapitalis dengan mengantongi izin mendirikan bangunan yang dikeluarkan oleh pemerintah. Beberapa kasus menunjukkan jika di suatu lokasi terjadi alih fungsi lahan, maka dalam waktu yang tidak lama lahan disekitarnya juga beralih fungsi secara progresif. Pada Kecamatan Biringkanaya Kota Makassar, perubahan alih fungsi lahan terjadi disebabkan oleh semakin meningkatnya jumlah penduduk, serta banyaknya kebutuhan untuk kegiatan non pertanian. Ini juga disebabkan karena letak kecamatan Biringkanaya terletak pada daerah perkotaan sehingga perubahan alih fungsi lahan meningkat sangat pesat.

Berdasarkan data dari Badan Pusat Statistik Kota Makassar Tahun 2013 (BPS, 2013) mencatat bahwa luas lahan tambak di Kecamatan Biringkanaya seluas 479 ha. Selengkapnya dapat dilihat pada Tabel 5. di bawah ini.

Tabel 5. Perbandingan Luas Tambak Berdasarkan Data Badan Pusat Statistik dan Hasil Klasifikasi Citra.

\begin{tabular}{|c|c|c|c|}
\hline \multirow{2}{*}{$\begin{array}{c}\text { Penggunaan } \\
\text { Lahan } \\
\text { Tambak }\end{array}$} & $\begin{array}{c}|c| \\
\text { Badan Pusat } \\
\text { Statistik } \\
\text { Tahun 2013 }\end{array}$ & $\begin{array}{c}\text { Citra } \\
\text { SPOT 4 } \\
\text { Tahun } \\
\mathbf{2 0 1 0}\end{array}$ & $\begin{array}{c}\text { Citra } \\
\text { Landsat 8 } \\
\text { Tahun 2016 }\end{array}$ \\
\hline Tambak & 479 & 329,17 & 200,2 \\
\hline
\end{tabular}

Selisih luas tambak antara data BPS 2013 dan hasil klasifikasi citra SPOT 4 tahun 2010 sebesar 149,83 ha dan antara data BPS 2013 dengan hasil klasifikasi citra Landsat 8 tahun 2016 sebesar 178,8 ha. Perbedaan ini disebabkan karena penelitian ini menggunakan metode penginderaan jarak jauh (remote sensing), sedangkan BPS yang langsung melakukan pengukuran di lapangan, sehingga lahan tambak dapat teridentifikasi dengan baik dan jelas.

Tabel 6. Luas Perubahan Penggunaan Lahan Tahun 2010-2016.

\begin{tabular}{|c|c|c|c|c|}
\hline \multirow{2}{*}{ Perubahan Lahan } & \multicolumn{2}{|c|}{ Tahun 2016 } & \multirow{2}{*}{ Total } \\
\cline { 3 - 4 } & $\begin{array}{c}\text { Tambak } \\
\text { (ha) }\end{array}$ & $\begin{array}{c}\text { Pemukiman } \\
\text { (ha) }\end{array}$ & \\
\hline \multirow{2}{*}{$\begin{array}{c}\text { Tahun } \\
2010\end{array}$} & $\begin{array}{c}\text { Tambak } \\
\text { (ha) }\end{array}$ & 168,8 & 160,37 & 329,17 \\
\cline { 2 - 4 } & $\begin{array}{c}\text { Pemukiman } \\
\text { (ha) }\end{array}$ & 31,4 & $3.322,82$ & $3.34,22$ \\
\hline \multicolumn{2}{|c|}{ Total } & 200,2 & $3.483,19$ & $\mathbf{3 . 6 8 3 , 3 9}$ \\
\hline
\end{tabular}


Berdasarkan hasil overlay perubahan lahan tahun 2010 dan tahun 2016 menghasilkan perubahan warna dalam interpretasi citra sebagai berikut :

1. Lahan tambak yang tetap menjadi tambak sebesar 161,54 ha. Berikut adalah Gambar 7., peta hasil overlay tambak yang tetap tambak pada tahun 2010-2016 Kecamatan Biringkanaya.

2. Perubahan lahan tambak menjadi pemukiman pada hasil overlay yaitu sebesar 168,62 ha. Berikut adalah Gambar 8., peta hasil overlay lahan tambak menjadi pemukiman pada tahun 2010-2016 Kecamatan Biringkanaya.

3. Perubahan pemukiman menjadi lahan tambak pada hasil overlay yaitu sebesar 31,4 ha. Berikut adalah Gambar 9., peta hasil overlay lahan pemukiman menjadi lahan tambak pada tahun 2010-2016 Kecamatan Biringkanaya.

4. Lahan pemukiman yang tetap menjadi pemukiman sebesar 3.321,83 ha. Berikut adalah Gambar 10., peta hasil overlay pemukiman yang tetap pemukiman pada tahun 2010-2016 Kecamatan Biringkanaya.

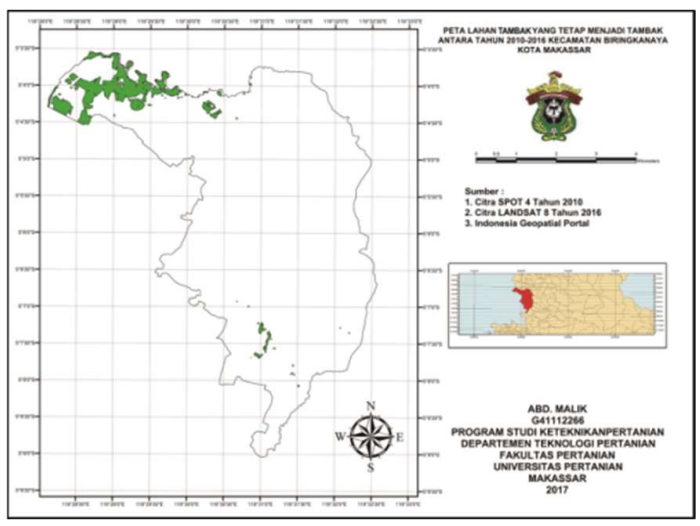

Gambar 7. Peta Perubahan Lahan Tambak yang tetap Lahan Tambak pada Tahun 2010-2016

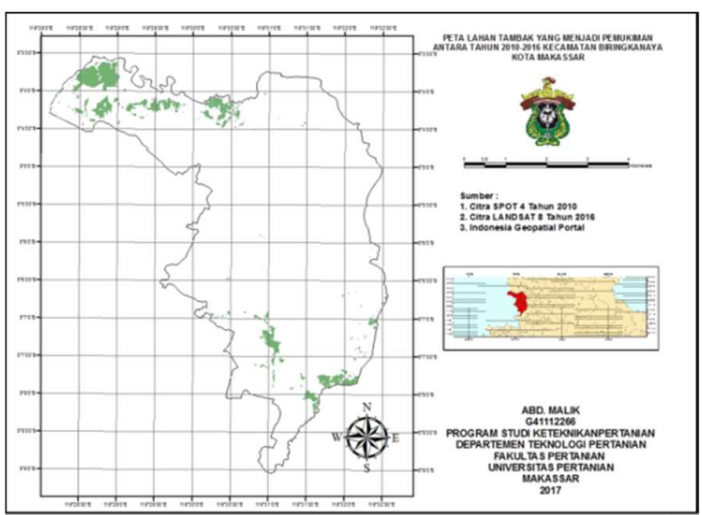

Gambar 8. Peta Perubahan Lahan Tambak menjadi Pemukiman pada Tahun 2010-2016

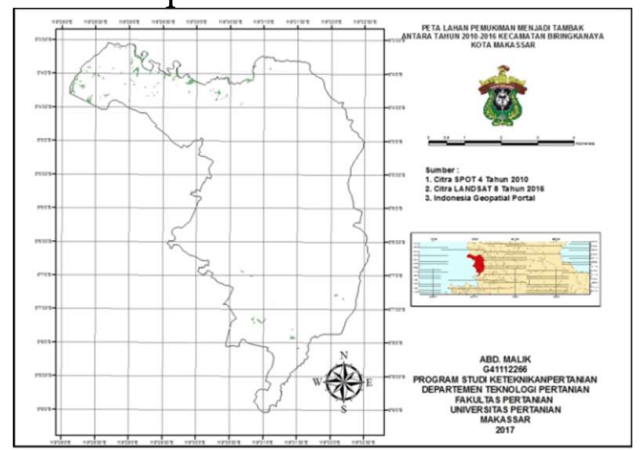

Gambar 9. Peta Perubahan Lahan Pemukiman menjadi Lahan Tambak pada Tahun 20102016

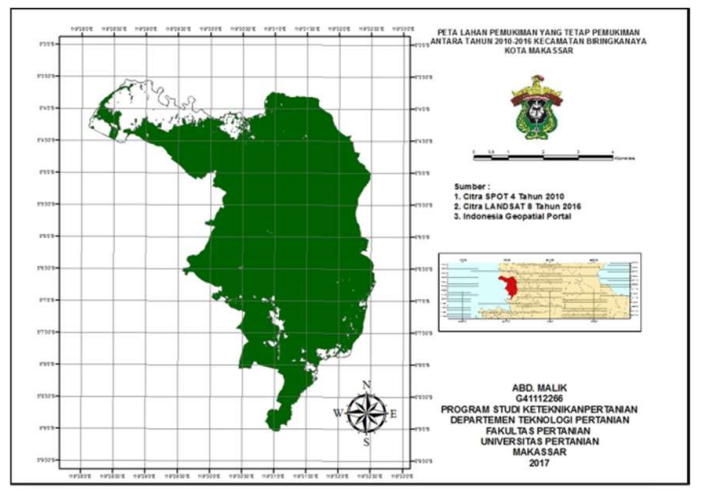

Gambar 10. Peta Perubahan Lahan Pemukiman yang tetap Pemukiman pada Tahun 2010-2016

\section{Validasi Akurasi Citra}

Dari pengamatan langsung di lapangan dengan membandingkan hasil klasifikasi citra maka diperoleh hasil validasi pada Tabel 7. dibawah ini : 
Tabel 7. Hasil Validasi Citra Tahun 2016

\begin{tabular}{|c|c|c|c|c|}
\hline \multirow{3}{*}{$\begin{array}{c}\text { Data Hasil } \\
\text { Klasiflkasi }\end{array}$} & \multicolumn{3}{|c|}{ Data Acuan Lapangan } & \multirow{2}{*}{ Total } \\
\cline { 2 - 4 } & Tambak & Tambak & Pemukiman & \\
\cline { 2 - 4 } & Pemukiman & 5 & 6 & 50 \\
\hline \multicolumn{2}{|c|}{ Total } & 49 & 45 & 50 \\
\hline
\end{tabular}

Dari hasil validasi citra dan pengamatan langsung di lapangan, jumlah titik yang teridentifikasi sebagai lahan tambak adalah 44 titik dan titik yang terbaca sebagai lahan pemukiman yaitu terdiri dari 6 titik dari 50 titik acuan, sedangkan jumlah titik yang teridentifikasi sebagai pemukiman yaitu 45 titik dan titik yang terbaca sebagai lahan tambak yaitu terdiri dari 6 titik dari 50 titik acuan.

\section{Analisis Tingkat Akurasi Citra}

Dari hasil validasi citra dan perhitungan yang dilakukan, maka diperoleh persentase producer accuracy (untuk mengetahui tingkat akurasi berdasarkan fakta yang diperoleh di lapangan), ommission error (untuk mengetahui kesalahan yang terjadi pada pembacaan citra dengan melihat kenyataan di lapangan), user accuracy (untuk mengetahui tingkat akurasi berdasarkan hasil pembacaan citra), commission error (untuk mengetahui kesalahan yang terjadi pada proses identifikasi citra yang dilakukan pada perangkat lunak pengolah citra data raster dan vektor). Untuk masing-masing tiap kelas penggunaan lahan sebagai berikut :

Tabel 8. Akurasi Citra Tahun 2016

\begin{tabular}{|c|c|c|c|c|}
\hline $\begin{array}{c}\text { Penggunaan } \\
\text { Lahan }\end{array}$ & $\begin{array}{c}\text { Producer } \\
\text { Accuracy } \\
\text { (\%) }\end{array}$ & $\begin{array}{c}\text { Ommissi } \\
\text { on Error } \\
(\%)\end{array}$ & $\begin{array}{c}\text { User } \\
\text { Accura } \\
\text { cy (\%) }\end{array}$ & $\begin{array}{c}\text { Commiss } \\
\text { ion Error } \\
(\%)\end{array}$ \\
\hline Tambak & 89,79 & 10,21 & 88 & 12 \\
\hline Pemukiman & 88,24 & 11,76 & 90 & 10 \\
\hline
\end{tabular}

Tabel 8. di atas menunjukkan bahwa persentase tingkat akurasi setiap penggunaan lahan bervariasi. Producer accuracy untuk penggunaan lahan tambak sebesar 89,79\%, user accuracy sebesar $88 \%$. Pada pemukiman producer accuracy sebesar 88,24\% dan user accuracy sebesar $90 \%$. Matriks kesalahan dapat dilihat pada persentase ommission error dan commission error pada Tabel 12 . Ommision error untuk lahan tambak sebesar $10,21 \%$ sedangkan pemukiman sebesar $11,76 \%$. Commision error pada lahan tambak sebesar $12 \%$ dan pada pemukiman sebesar $10 \%$.

Nilai overall accuracy untuk tahun 2016 adalah sebesar 89\%. Hal ini sesuai dengan pendapat United State Geological Survey (USGS) (2002), bahwa tingkat ketelitian sebagai kriteria utama bagi sistem klasifikasi penutupan atau penggunaan lahan yang disusun yaitu tingkat ketelitian klasifikasi/interpretasi minimum dengan menggunakan penginderaan jauh tidak kurang dari $85 \%$. Kesalahan (error) yang sering terjadi dalam penelitian ini adalah mengkategorikan lahan tambak sebagai pemukiman atau sebaliknya pemukiman sebagai lahan tambak. Pada penelitian ini citra digunakan itu tepat pada bulan kering, sehingga untuk membedakan piksel pada tutupan lahan yang satu dengan yang lain harus benar-benar melakukan proses klasifikasi sesuai dengan identifikasi warna yang ada pada citra. Sekitar 6 training area yang teridentifikasi sebagai lahan tambak ternyata titik tersebut adalah pemukiman dan 5 training area teridentifikasi sebagai pemukiman ternyata titik tersebut adalah lahan tambak.

\section{PENUTUP}

\section{Kesimpulan}

Berdasarkan penelitian yang telah dilakukan, maka dapat disimpulkan bahwa:

1. Perubahan lahan di Kecamatan Biringkanaya Kota Makassar pada tahun 2010 hingga 2016 yaitu lahan tambak yang tetap sebagai lahan tambak sebesar 161,8 ha $(5 \%)$, lahan tambak menjadi lahan pemukiman sebesar 160,37 ha $(4 \%)$, lahan pemukiman menjadi lahan tambak sebesar 31,4 ha (1\%) dan lahan pemukimantetap sebagai lahan pemukiman sebesar 3321,83 ha $(90 \%)$. 
ISSN: 1979-7362

2. Tingkat akurasi citra sebesar $78 \%$ dan nilai overall accuracy sebesar $89 \%$.

\section{Saran}

Hasil penelitian ini dapat digunakan untuk melakukan penelitian lebih lanjut mengenai penggunaan lahan yang ada di Kecamatan Biringkanaya Kota Makassar baik yang mengenai penggunaan lahan maupun penelitian lainnya.

\section{DAFTAR PUSTAKA}

Badan Informasi Geospasial. 2016. Peta Rupa Bumi. Bogor

Badan Pusat Statistik. 2013. Kota Makassar Dalam Angka. Sulawesi Selatan.

Badan Pusat Statistik. 2014. Kecanatab Biringkanaya Dalam Angka. Sulawesi Selatan.

Barkey R. A., A. Achmad, S. Rijal, A. S. Mahbub, A. S. Soma, dan A. B. Talebe. 2009. Buku Ajar Sistem Informasi Spasial Kehutanan. Fakultas Kehutanan Universitas Hasanuddin, Makassar.

Biggs, J., P. Wlliams, P. Whitfield, P. Nicolet \& A. Weatherby, 2005. 15 years of pond assessment in Britain: Marine and Freshwater Wcosystems $15: 693-714$.

Budiyanto, Eko. 2010. Sistem Informasi Geografis dengan ArcView GIS. Penerbit ANDI. Yogyakarta.

Ekadinata A., S. Dewi, D. P. Hadi, D. K. Nugroho, dan F. Johana. 2008. Sistem Informasi Geografis Untuk Pengelolaan Bentang Lahan Berbasis Sumber Daya Alam. World Agroforestry Centre, Bogor, Indonesia

Ekadinata A., S. Dewi, D. P. Hadi, D. K. Nugroho, dan F. Johana. 2008. Sistem
Informasi Geografis Untuk Pengelolaan Bentang Lahan Berbasis Sumber Daya Alam. World Agroforestry Centre, Bogor, Indonesia.

Jaya.I.N.S. 2002.Penginderaan Jauh Satelit untuk Kehutanan. Laboratorium Inventarsisasi Hutan, Jurusan Manjemen Hutan, Fakultas Kehutanan IPB

Prahasta, E. 2002.Konsep-konsep Dasar Sistem Informasi Geografis. SIG: Tutorial ArcView. Penerbit Informatika: Bandung.

Pratomo, D. Guruh. 2004. Pendidikan dan Pelatihan (DIKLAT) Teknis Pengukuran dan Pemetaan Kota. Institut Teknologi Sepuluh Nopember. Surabaya.

Purwadhi, Sri Hardiyanti. 2009. Pengantar Interpretasi Citra Penginderaan Jauh. Lembaga Penerbangan dan Antariksa Nasional dan Univeritas Negeri Semarang.

Saifullah.2002 Rencana Tata Ruang Kawasan Pesisir Teluk Saleh Kabupaten Dompu. Usulan Thesis. Program Studi Pengelolaan Sumberdaya Pesisir dan Lautan Program Pascasarjana Institut Pertanian Bogor. Bogor.

USGS. 2002. Landsat 7 Science Data User Handbook.

Utomo. W. H., 1989, Konservasi Tanah di Indonesia. Penerbit Rajawali Pers. Jakarta. 